\title{
Self-Awareness and Analytical Thinking: Overcoming the Pitfalls of the Attribution Process
}

\author{
Olivia Murphy ${ }^{1}$ \\ ${ }^{1}$ RMIT University
}

April 28, 2020

No content was found during Document Import. Please contact help@authorea.com for support.

\section{Hosted file}

Overcoming the Pitfalls of the Attribution Process - Olivia Murphy (s3723233) (Final Draft).pdf available at https : //authorea . com/users/277678/articles/395328-self-awareness-and-analyticalthinking-overcoming-the-pitfalls-of-the-attribution-process 